\title{
Research
}

\section{Development of prescribing-safety indicators for GPs using the RAND Appropriateness Method}

\begin{abstract}
\section{Background}

In the UK, a process of revalidation is being introduced to allow doctors to demonstrate that they meet current professional standards, are up-to-date, and fit to practise. Given the serious risks to patients from hazardous use of medicines it will be appropriate, as part of the revalidation process, to assess the safety of prescribing by GPs.
\end{abstract}

\section{Aim}

To identify a set of potential prescribing-safety indicators for the purposes of revalidation of individual GPs in the UK.

\section{Design and setting}

The RAND Appropriateness Method was used to identify, develop, and obtain agreement on the indicators in UK general practice.

\section{Method}

Twelve GPs from across the UK with a wide variety of characteristics assessed indicators for appropriateness of use in revalidation

\section{Results}

Forty-seven safety indicators were considered appropriate for assessing the prescribing safety of individual GPs for the purposes of revalidation lappropriateness was defined as an overall panel median score of $\geq 7$ lon a 1-9 scale), with no more than three panel members rating the indicator outside the 3-point distribution around the median]. After removing indicators that were variations on the same theme, a final set of 34 indicators was obtained these cover hazardous prescribing across a range of therapeutic areas, hazardous drugdrug combinations, prescribing with a history of allergy, and inadequate laboratory-test monitoring.

\section{Conclusion}

This study identified a set of 34 indicators that were considered, by a panel of $12 \mathrm{GPs}$, to be appropriate for use in assessing the safety of GP prescribing for the purposes of revalidation. Violation of any of the 34 indicators indicates a potential patient-safety problem.

\section{Keywords}

consensus; medication errors; primary health care; professional practice; quality indicators: safety.

\section{INTRODUCTION}

Medication prescription is one of the most powerful tools for GPs in the prevention and treatment of disease and the alleviation of symptoms. Nearly 800 million prescriptions are dispensed annually in the community in England. ' However, medication-related adverse events are an important source of patient morbidity, many cases of which could be prevented by the highest-quality prescribing and medicines management. ${ }^{2-5}$

Revalidation is a single, integrated process that allows doctors working in the UK to demonstrate that they meet current professional standards, are up-to-date, and fit to practise, by providing supporting information in a revalidation portfolio. Pilots of revalidation are currently ongoing. For GPs, the Royal College of General Practitioners (RCGP) is proposing standards and methods that must be approved by the General Medical Council these include prescribing-safety indicators. Given the importance of prescribing by GPs, it is appropriate that potential indicators of the quality and safety of prescribing are considered in any scheme for revalidation.

There have been many attempts over recent years to develop prescribing indicators in the UK, ${ }^{7}$ such as those based on the interrogation of prescriptions issued by GPs (for example, using prescribing analysis and cost tabulation data ${ }^{8}$.

AJ Avery, BMedSci (Hons), DM, FRCGP, professor of primary health care; GM Dex, MSc, DRCOG MRCGP, clinical lecturer; C Mulvaney, PhD, MSc, BSc (Hons), RGN, senior research fellow; B Serumaga, BPharm, MPH, PhD, FPPR honorary lecturer; R Spencer, BMBS, BMedSci, academic clinical fellow, Division of Primary Care, School of Community Health Sciences, University of Nottingham, Queens Medical Centre,

Nottingham. HE Lester, MBBCh, MD, professor of primary care; SM Campbell, BA (Hons), MA, PhD, senior research fellow, Health Sciences Research Group, School of Community Based Medicine, University of Manchester, Manchester.
Although potentially useful for analysing prescribing patterns, these data are rarely linked to diagnoses and patient characteristics, and so have limitations when assessing quality and safety. Other indicators have required very detailed analysis and assessment of clinical records Ifor example, the medication appropriateness index 9 , which would not be feasible for the large-scale assessment of all GPs in the UK.

The evidence base for developing quality indicators for safe prescribing is limited; however, systematically combining available evidence with expert professional opinion using a consensus methodology can create quality indicators in areas where it would not otherwise be possible. ${ }^{10}$ Moreover, with developments in methods for interrogating electronic medical records, there is now the opportunity in the UK to develop and use sophisticated indicators that can give an assessment of the quality and safety of prescribing by individual GPs.

This study aimed to identify a set of potential prescribing-safety indicators for the purposes of revalidation of individual GPs in the UK, contextualised by the wider implementation of revalidation.

\section{METHOD}

Identification of indicators

\section{Address for correspondence}

Tony Avery, Division of Primary Care, School of Community Health Sciences, University of Nottingham Medical School, Queen's Medical Centre, Nottingham NG7 2UH.

E-mail: tony.averyanottingham.ac.uk

Submitted: 31 August 2010; Editor's response: 23 September 2010; final acceptance: 6 December 2010.

\section{OBritish Journal of General Practice}

This is the full-length article (published online 1 Aug 2011) of an abridged version published in print. Cite this article as: $\mathbf{B r} \mathbf{J}$ Gen Pract 2011; DOI: 10.3399/bjgp11X588501. 


\section{How this fits in}

GPs have a critically important role in patient safety through the judicious prescription, and careful monitoring, of patients' medicines. Nevertheless, many patients are put at risk, and some are harmed, as a result of hazardous prescribing in general practice. Therefore, assessing the safety of prescribing by GPS is an important facet of any system for assessing fitness to practise. One way of doing this is by using prescribing-safety indicators, which have been developed in other areas of medicine. This article describes the development of a set of prescribing-safety indicators for use in general practice, with a specific focus on their use in revalidation in the UK.

Potential indicators that described a pattern of prescribing that could be hazardous and may put patients at risk of harm were identified. Potential indicators that were not suitable for assessing the prescribing of individual doctors and where the prospects were low for extracting relevant data from GP clinical computer systems were excluded. The inclusion and exclusion criteria are shown in Box 1.

Multiple sources of information were used to identify potential indicators; ${ }^{11-24}$ these are outlined in Table 1. These sources were identified by one of the researchers with the help of a reference group between August 2008 and March 2009. The indicators developed in this project were derived mostly from existing sources because of the considerable amount of work that has been done on prescribing-safety indicators in other countries and other settings. ${ }^{11-24}$ Over 400 prescribing indicators were reviewed against the inclusion and exclusion criteria and against attributes of good indicators, including importance, validity, and feasibility of data collection using electronic health records. ${ }^{10,25}$

After removing duplicates, 50 indicators were considered suitable for inclusion in round one of the subsequent consensus technique. Of these, 44 came from a least one of the sources highlighted in Table 1; four came only from the British National Formulary $(B N F)^{14}$ and two only from the draft design specification for NHS IT systems. ${ }^{15}$

Defining the indicators and evidence base In most cases, indicators were defined according to the wording used in previously published studies and reports but, in some instances, this was altered either to make the indicators more relevant to UK general practice or to give more specific detail regarding the drugs and conditions covered. For 13 of the indicators, one or more variations in the text were produced; this resulted in a total of 68 indicator statements for the 50 indicators. As an example, although the prescription of $\beta$-blockers is contraindicated in asthma, there is evidence to suggest that in various types of heart disease, such as heart failure, the benefits may outweigh the risks; therefore, a variation on an asthma/ $\beta$-blocker indicator would be to exclude patients with cardiac conditions where benefits of $\beta$-blockers may outweigh the risks.

Electronic searches of the literature were conducted and respected reference sources, such as the BNF,14 Martindale: The Complete Drug Reference, ${ }^{26}$ and Stockley's Drug Interactions, ${ }^{27}$ were drawn on. Indicators were also shown to the team responsible for developing the content of the $B N F$, who provided additional background evidence. The supporting evidence base was summarised in an evidence-based synopsis for each of the potential indicators.

The reasons why the different types of indicators did not yield many candidate indicators from the sources included are shown in Table 1. For example, many Assessing Care of Vulnerable Elders ${ }^{11}$ indicators developed in the US, relate to process measures rather than prescribing decisions that can be attributed to one GP; likewise, some of the Beers criteria ${ }^{13}$ and indicators of the Screening Tool of Older Persons' potentially inappropriate Prescriptions (STOPP) ${ }^{24}$ relate more to the appropriateness of prescribing than safety.

The indicators were presented in the following categories:

- A: cardiovascular and respiratory disease;

- B: central nervous system lincluding analgesics);

- C: anti-infective agents;

- D: women's health and urinary disorders;

- E: musculoskeletal;

- F: hazardous co-prescriptions, interactions, and allergy; and

- G: laboratory-test monitoring.

\section{Consensus process}

The RAND Appropriateness Method was used to select the most appropriate indicators. This method seeks to combine scientific evidence with the collective 
judgement of experts: a consensus opinion is derived from a group, with individual opinions aggregated into refined aggregated opinion. ${ }^{25,28,29}$ A 12-member panel was appointed. Two GPs with known expertise in therapeutics and one with experience of working with the British Medical Association's General Practitioners' Committee were purposely selected. The remaining nine panelists were identified by writing to all RCGP faculties in the UK in March 2009 to ask for volunteers, which resulted in 58 replies. The following factors were taken into account when selecting the remaining panelists:

- professional background (practising GPs);

- employment status la range different types of GP, including partners, salaried GPs, a retainer-scheme GP, and a locum);

- sex (an equal mix of males and females);

- geography (GPs from each of the three countries of the UK); and

- professional roles lsome GPs with experience of working as appraisers/ assessors of GPs).

It was estimated that each member of the panel committed at least 3 days of work to the consensus-building exercise; they were partially reimbursed for their time.

\section{Data analyses}

This study adhered to the RAND Appropriateness Method by conducting a two-round consensus process. In round one, which was conducted by email in June 2009, panel members were asked to consider each indicator on its own merits using the summarised evidence for each as well as their own experience as practitioners.

In round two, panelists met for a 1-day face-to-face meeting in July 2009, where, under the chairmanship of two moderators, they discussed each indicator in turn as a group and then re-rated the indicators on individual rating sheets. These round-two rating sheets included feedback from the first round, presenting the frequency distribution of ratings of all panelists across the 9-point scale, the overall panel median rating, and, for each panelist, a reminder of how they had rated each indicator in round one. Although panel members were made aware of their own ratings from the first round, the scores from other panel members were anonymised.
During round two, panelists were also asked to consider whether they wished to propose an alternative wording for each indicator or propose any additional indicators. This resulted in wording changes for 21 indicators and two new ones. Each of the indicators - whether original, revised, or new - was scored by each of the panel members.

In both rounds, panelists were asked to rate each indicator on a 9-point integer scale. A rating of 1 meant that, in their opinion, it would be extremely inappropriate to use the indicator, whereas a rating of 9 meant its use would be extremely appropriate. The overall panel median ratings were as follows:

- 1-3: inappropriate;

- 4-6: equivocal, or unsure of appropriateness; and

- 7-9: appropriate.

Using the consensus technique, there was another aspect to the rating process, namely, the level of agreement within a panel for each scale for each indicator. Agreement signified that $80 \%$ of panelists' ratings were within the same 3 -point region (that is, 1-3, 4-6, 7-9), as the observed median. To be included in the final recommended set of indicators, therefore, 'appropriate' was defined as an overall panel median score of $\geq 7$, with no more than three panel members rating the indicator outside the 3-point distribution around the median; for example, if the median score was 7, no more than three panel members gave a score $<6$ or $>8$. Results are presented for the final (roundtwol ratings only.

\section{RESULTS}

Ninety-two indicators were considered in round two of the exercise; the full results are shown in Appendix 1. Forty-seven prescribing-safety indicators were considered appropriate for assessing the prescribing safety of individual GPs for the purposes of revalidation loverall panel median rating of 7-9 with agreement); these are shown in bold in Appendix 1). These consisted of 32 originally worded indicators, along with 13 variations on these and two that were suggested by the expert panel during round two. Six indicators were rated inappropriate for assessing the prescribing safety of individual GPs for the purposes of revalidation loverall panel rating of 1-3 with agreement). The remaining indicators were rated as equivocal. 


\section{Table 1. Sources of the reviewed prescribing indicators}

\begin{tabular}{|c|c|c|c|}
\hline Source & $\begin{array}{l}\text { Indicators } \\
\text { reviewed }(n)\end{array}$ & $\begin{array}{l}\text { Indicators from each } \\
\text { source included in } \\
\text { round one of } \\
\text { consensus process }^{\mathrm{a}}(n)\end{array}$ & Source details \\
\hline $\begin{array}{l}\text { Assessing Care of } \\
\text { Vulnerable } \\
\text { Elders (ACOVE) }{ }^{11,12}\end{array}$ & 217 & 2 & $\begin{array}{l}\text { This RAND project }{ }^{11} \text { developed a set of evidence- } \\
\text { based, quality-of-care indicators relevant to } \\
\text { vulnerable older people using systematic literature } \\
\text { reviews, expert opinion, and guidance from expert } \\
\text { groups and stakeholders. The indicators have } \\
\text { been considered for use in the UK }{ }^{12}\end{array}$ \\
\hline Beers criteria $^{13}$ & 89 & 20 & $\begin{array}{l}\text { A set of criteria from the US for assessing potentially } \\
\text { inappropriate medication use in people aged } \\
\geq 65 \text { years. The original list of criteria were published } \\
\text { in the } 1990 \text { s and updated in } 2003^{13}\end{array}$ \\
\hline
\end{tabular}

Relevance to prescribing-safety indicators for revalidation

Many of these indicators relate to process measures and the care of patients with long-term conditions, rather than to prescribing decisions that could easily be attributed to one GP

\begin{tabular}{|c|c|c|c|}
\hline $\begin{array}{l}\text { British National } \\
\text { Formulary }(B N F)^{14}\end{array}$ & N/A & 4 & $\begin{array}{l}\text { Four of the indicators came only from the } B N F \text {, } \\
\text { which was also used to check the validity } \\
\text { of many of the other potential indicators }\end{array}$ \\
\hline $\begin{array}{l}\text { Draft design } \\
\text { specification for NHS IT } \\
\text { systems aimed at } \\
\text { minimising risk of harm }\end{array}$ & N/A & 2 & $\begin{array}{l}\text { This report included a comprehensive literature } \\
\text { review on risks of harm from medications in } \\
\text { primary care and provides examples of } \\
\text { hazardous prescribing }\end{array}$ \\
\hline
\end{tabular}

from medications ${ }^{15}$

\begin{tabular}{lll}
\hline $\begin{array}{l}\text { Medication } \\
\text { Appropriateness }\end{array}$ & N/A & N/A
\end{tabular}$\quad \begin{aligned} & \text { A method for assessing the appropriateness of } \\
& \text { medication based on a range of factors such as }\end{aligned}$

Index ${ }^{9} \quad$ indication, evidence for effectiveness, and directions and absence of important contraindications. It lends itself best to detailed analysis of prescribing based on clinical judgement, rather than interrogation of electronic medical records

\begin{tabular}{|c|c|c|c|c|}
\hline $\begin{array}{l}\text { National Patient } \\
\text { Safety Agency (NPSA) } \\
\text { documents }^{16-18}\end{array}$ & $\mathrm{~N} / \mathrm{A}$ & $\mathrm{N} / \mathrm{A}$ & $\begin{array}{l}\text { The NPSA }{ }^{16} \text { has produced a number of documents } \\
\text { that are relevant to the safety of prescribing in } \\
\text { primary care. }{ }^{17} \text { For example, the fourth report from } \\
\text { the Patient Safety Observatory }{ }^{18} \text { highlighted medication } \\
\text { incidents in the community and at the interface betwee } \\
\text { community and hospital care, as well as suggesting } \\
\text { ways in which risks of harm could be reduced. } \\
\text { The NPSA has highlighted a number of specific } \\
\text { safety issues relevant to primary care, including } \\
\text { anticoagulant prescribing, dosing errors with opioid } \\
\text { medicines, and the prescribing of methotrexate }{ }^{17}\end{array}$ & $\begin{array}{l}\text { Information from NPSA documents used to } \\
\text { help inform the prescribing-safety } \\
\text { indicators project } \\
\text { en } \\
\text { en }\end{array}$ \\
\hline $\begin{array}{l}\text { The National Service } \\
\text { Framework for Older } \\
\text { People (NSF }{ }^{19} \text { and } \\
\text { Medicines for Older } \\
\text { People: Implementing } \\
\text { Medicines-Related } \\
\text { Aspects of the NSF } \\
\text { for Older People }\end{array}$ & $\mathrm{N} / \mathrm{A}$ & $\mathrm{N} / \mathrm{A}$ & $\begin{array}{l}\text { These documents raise important issues regarding } \\
\text { medicines used in older people }\end{array}$ & $\begin{array}{l}\text { Specific indicators for assessing the quality } \\
\text { and safety of prescribing are not explicitly } \\
\text { suggested, although many of the issues } \\
\text { raised are covered in the approaches taken } \\
\text { by Assessing Care of Vulnerable Elders and } \\
\text { Beers criteria }\end{array}$ \\
\hline $\begin{array}{l}\text { PINCER trial } \\
\text { indicators }\end{array}$ & 11 & 6 & $\begin{array}{l}\text { A cluster randomised trial took place in the UK } \\
\text { between } 2005 \text { and } 2009 \text { to assess a pharmacist-led } \\
\text { intervention versus simple feedback in correcting } \\
\text { clinically important problems in medicines management } \\
\text { in general practices in England. The outcome measures } \\
\text { for the trial represent important examples of } \\
\text { hazardous prescribing, inadequate monitoring, and } \\
\text { potentially hazardous dosage instructions }{ }^{21}\end{array}$ & $\begin{array}{l}\text { Most of these indicators were considered } \\
\text { relevant } \\
\text { s }\end{array}$ \\
\hline $\begin{array}{l}\text { Preventable drug- } \\
\text { related morbidity }{ }^{22} \\
\text { indicators }\end{array}$ & 29 & 4 & $\begin{array}{l}\text { Based on identifying preventable morbidity associated } \\
\text { with drug use. The University of Manchester has } \\
\text { adapted US indicators for use in the UK and, } \\
\text { along with the University of Nottingham, has } \\
\text { successfully used these indicators of electronic } \\
\text { health records in general practices in England² }\end{array}$ & $\begin{array}{l}\text { These indicators focus on a preventable } \\
\text { morbidity associated with drug use, but } \\
\text { from this information it would be difficult } \\
\text { using electronic searches to identify which } \\
\text { doctor(s) were responsible for the } \\
\text { prescribing (or monitoring failures) that led } \\
\text { to the preventable morbidity }\end{array}$ \\
\hline
\end{tabular}




\section{Table 1 continued. Sources of the reviewed prescribing indicators}

\begin{tabular}{|c|c|c|c|c|}
\hline Source & $\begin{array}{l}\text { Indicators } \\
\text { reviewed (n) }\end{array}$ & $\begin{array}{l}\text { Indicators from each } \\
\text { source included in } \\
\text { round one of } \\
\text { consensus process }^{\text {a }}(n)\end{array}$ & Source details & $\begin{array}{l}\text { Relevance to prescribing-safety indicators } \\
\text { for revalidation }\end{array}$ \\
\hline $\begin{array}{l}\text { Quality and Outcomes } \\
\text { Framework (QOF) }{ }^{23}\end{array}$ & 8 & 0 & $\begin{array}{l}\text { The QOF contains a number of prescribing- related } \\
\text { indicators. Most of these relate to the need to } \\
\text { prescribe a particular drug for a particular clinical } \\
\text { condition. There are also more general indicators } \\
\text { of prescribing, including the need to undertake } \\
\text { medication reviews }\end{array}$ & $\begin{array}{l}\text { Indicators relate to the need to prescribe a } \\
\text { particular drug for a particular clinical } \\
\text { condition, which is considered outside the } \\
\text { scope of the current exercise. The more } \\
\text { general indicators of prescribing, such as } \\
\text { the need to undertake medication reviews, } \\
\text { cannot easily be applied to the prescribing } \\
\text { of an individual GP in a group practice or } \\
\text { assessed through interrogation of the } \\
\text { electronic health record }\end{array}$ \\
\hline $\begin{array}{l}\text { Screening Tool of } \\
\text { Older Persons' } \\
\text { potentially inappropriate } \\
\text { Prescriptions (STOPP) } \\
\text { and Screening Tool to } \\
\text { Alert doctors to Right } \\
\text { Treatment (START) }{ }^{24}\end{array}$ & 65 & 27 & $\begin{array}{l}\text { These sets of indicators have been developed } \\
\text { to assess the appropriateness of prescribing for } \\
\text { older people. The tools have been developed and } \\
\text { validated by a team from Cork, Republic of Ireland }\end{array}$ & $\begin{array}{l}\text { Many of these indicators were considered } \\
\text { highly relevant to general practice; } \\
\text { variations on } 27 \text { of them were put to the } \\
\text { consensus panel. STOPP indicators not } \\
\text { included were not considered, by the } \\
\text { research team, to be of high enough clinical } \\
\text { importance for the purposes of revalidation, } \\
\text { or it would be very difficult to extract } \\
\text { relevant data from GP computer systems }\end{array}$ \\
\hline
\end{tabular}

${ }^{a}$ As there was some overlap in indicators between the different sources, after removing duplicates, 50 indicators (and a total 68 indicator statements) were included in round one.

After removing indicators that were variations on the same theme, 34 that were rated as appropriate for use in assessing the prescribing safety of individual GPs for the purposes of revalidation were identified; these are shown in Box 2. Variations on indicators that were either most strongly rated by panelists or were most comprehensive were selected - for example, panelists rated indicators involving benzodiazepines more strongly where these indicators also contained Z-drugs.

\section{DISCUSSION}

\section{Summary}

Thirty-four prescribing-safety indicators were identified as appropriate for use in assessing the prescribing safety of individual GPs for the purposes of revalidation. These cover hazardous prescribing across a range of therapeutic areas, hazardous drug-drug combinations, prescribing with a history of allergy, and inadequate laboratory-test monitoring.

\section{Strengths and limitations}

The strengths of the study include the wide range of sources used to identify prescribing-safety indicators as well as the involvement of both a reference group and staff editors from the BNF to validate aspects of the work and the evidence base. Each indicator was accompanied by an evidence-based summary. The panel consisted of GPs with a wide range of characteristics. Although over 400 potential prescribing indicators were reviewed, only those appropriate for use in the assessment of the prescribing safety of individual GPs for the purposes of revalidation were included. This study also adhered to a validated systematic consensus method for developing appropriateness scenarios. ${ }^{29}$

The indicators were not defined so they could be immediately converted into reliable and unambiguous queries for running on GP computer systems, as with the PINCER trial. ${ }^{21}$ In addition, the indicators were not phrased in such a way as to take account of a doctor's volume of prescribing (whereby instances of hazardous prescribing might be considered as a proportion of overall numbers of prescriptions).

For each of the potential indicators, the supporting evidence base was summarised by undertaking electronic searches of the literature and drew on respected reference sources, such as the $B N F_{1}^{14}$ Martindale: The Complete Drug Reference, ${ }^{26}$ and Stockley's Drug Interactions. ${ }^{27}$ Although it is possible that more extensive literature reviews would have identified further evidence or other sources of potential prescribing-safety indicators, the involvement of a reference group and consultation with the editors of the $B N F$ mitigate against this.

\section{Comparison with existing literature}

It was felt that the modified Beers criteria ${ }^{13}$ and STOPP indicators ${ }^{24}$ would be of 


\section{Box 2. Indicators rated as valid for assessing the prescribing safety of individual GPs}

\section{A: Cardiovascular and respiratory disease}

1. Beta-blocker to a patient with asthma (excluding patients who also have a cardiac condition, where the benefits of beta-blockers may outweigh the risks)

3. Digoxin at a dose $>125 \mu \mathrm{g}$ daily in a patient with renal impairment (for example, CKD 3 or worse)

4. Digoxin at a dose of $>125 \mu \mathrm{g}$ daily for a patient with heart failure who is in sinus rhythm

5. Diltiazem or verapamil in a patient with heart failure

6. Aspirin at a dose $>75 \mathrm{mg}$ daily for $\geq 1$ month in a patient aged $>65$ years

7. Long-acting beta-2 agonist inhaler to a patient with asthma who is not also prescribed an inhaled corticosteroid

\section{B: Central nervous system (including analgesics)}

8. Aspirin to a child aged $\leq 16$ years

9. Metoclopramide or prochlorperazine in a patient with Parkinson's disease

10. Benzodiazepine or Z-drug for $\geq 21$ days in a patient aged $>65$ years who is not receiving benzodiazepines or Z-drugs on a long-term basis

11. Initiation of benzodiazepine or Z-drugs basis for $\geq 21$ days in a patient $>65$ years with depression

\section{C: Anti-infective agents}

\section{Mefloquine to a patient with a history of convulsions}

\section{D: Women's health and urinary disorders}

13. Combined hormonal contraceptive to a woman with a history of venous or arterial thromboembolism

14. Oral or transdermal oestrogens to a woman with a history of breast cancer

15. Oral or transdermal oestrogen without progesterone in a woman with an intact uterus

16. Combined hormonal contraceptive to a woman aged $\geq 35$ years who is a current smoker

17. Combined hormonal contraceptive to a woman with body mass index $\geq 40$

\section{E: Musculoskeletal}

18. NSAID, without co-prescription of an ulcer healing drug, to a patient with a history of peptic ulceration

19. NSAID in a patient with heart failure

20. NSAID in a patient with chronic renal failure (for example, CKD 3 or worsel

21. Long-term ( $>28$ days) NSAID (except for ibuprofen $\leq 1200 \mathrm{mg}$ daily) in a patient aged $>65$ years

\section{F: Hazardous co-prescriptions, interactions, and allergy}

\section{Warfarin in combination with an oral NSAID}

23. Phosphodiesterase type-5 inhibitor (for example, sildenafil) to a patient who is also receiving a nitrate or nicorandil

24. Clarithromycin or erythromycin to a patient who is also receiving simvastatin, with no evidence that the patient has been advised to stop the simvastatin while taking the antibiotic

25. Potassium salt or potassium sparing diuretic (excluding aldosterone antagonists) to a patient who is also receiving an ACE inhibitor or angiotensin II receptor antagonist

26. Verapamil to a patient who is also receiving a beta-blocker drug

27. Penicillin-containing preparation to a patient with a history of allergy to penicillin

\section{G: Laboratory test monitoring}

28. Warfarin to a patient without a record of international normalised ratio having been measured within the previous 12 weeks (excluding patients who self monitor)

29. Amiodarone without a record of liver function being measured in the previous 9 months

30. Amiodarone without a record of thyroid function being measured within the previous 9 months

31. ACE inhibitor or angiotensin II receptor antagonist without a record of renal function and electrolytes being measured prior to starting therapy

32. Lithium without a record of a lithium level being measured within the previous 6 months

33. Methotrexate without a record of a full blood count within the previous 3 months

34. Methotrexate without a record of liver function having been measured within the previous 3 months

particular relevance to UK general practice, although fewer than half of the indicators from these sources were considered appropriate for use in revalidation. There are a number of reasons for this, such as the inclusion and exclusion criteria utilised, the perceived clinical importance of the indicators, and the focus on indicators for the purposes of revalidation. Nevertheless, the study shows the importance of giving careful consideration to the purpose for and setting in which they are planned to be used.

\section{Implications for research and practice}

This study has highlighted a number of issues that have implications for future research as well as the development and application of prescribing-safety indicators.
Ongoing work will now determine whether each indicator can be translated into a computer query capable of reliably assessing the prescribing safety of individual GPs; the use of these queries will then be tested on GP computer systems. If implemented, it will be important to determine whether the use of prescribingsafety indicators improves prescribing performance and patient outcomes.

There are other implications that must be noted. The evidence base for most of the indicators is weak. This is, perhaps, unsurprising given that clinical trials focus on demonstrating the efficacy of interventions, rather than their safety; nevertheless, few of the indicators that were identified would fulfil the evidence required 
for inclusion in, for example, the Quality and Outcomes Framework. 23,30 Building the evidence base would mean conducting further research on the harms associated with potentially hazardous prescribing and inadequate medication monitoring, as well as the extent to which avoiding/correcting hazardous prescribing and inadequate monitoring improves patient safety.

In addition, although several of the sources used took account of the most common and important medication errors and/or preventable adverse drug events in general practice, $15,21,22$ future pharmacoepidemiological studies might help to provide even better information for the development of prescribing-safety indicators.
It will be important to consider the ways in which the prescribing-safety indicators might be used. The primary purpose of this study was their use in revalidation, but the indicators could also be used for the purposes of audit, GP appraisal, and in intervention studies similar to the PINCER trial. ${ }^{21}$ Encouraging the use of the indicators for improving the safety of prescribing will be important.

This study identified a set of 34 indicators that were considered, by a panel of 12 GPs, to be appropriate for use in assessing the prescribing safety of GPs for the purposes of revalidation. Violation of any of these indicators points towards a potential patient-safety problem.

\section{Funding body}

This project was part-funded by the Academy of Medical Royal Colleges.

\section{Ethical approval}

Research ethics committee approval was not needed for this study.

\section{Provenance}

Freely submitted; externally peer reviewed.

\section{Competing interests}

The authors have declared no competing interests.

\section{Acknowledgements}

We thank the GPs who took part in the consensus process; the administrative staff at the Royal College of General Practitioners; Clare Randall for administrative support at the University of Nottingham; Malcolm Campbell, Mike Pringle, lan Purves, Martin Roland, and Martin Shelley, who were members of the reference group; and Colin Hunter and Nigel Sparrow who gave helpful advice throughout the course of the project.

\section{Discuss this article}

Contribute and read comments about this article on the Discussion Forum: http://www.rcgp.org.uk/bjgp-discuss 


\section{REFERENCES}

1. NHS Information Centre for Health and Social Care. Prescriptions dispensed in the community statistics for 1997 to 2007: England. London: The

Information Centre (Health Centre), 2008.

http://www.ic.nhs.uk/webfiles/publications/PCA\%20publication/Final\%20vers on\%20210708.pdf (accessed 4 Apr 2011).

2. Howard RL, Avery A, Howard PD, Partridge M. Investigation into the reasons for preventable drug related admissions to a medical admissions unit: observational study. Qual Saf Health Care 2003; 12(4): 280-285.

3. Howard RL, Avery AJ, Slavenburg S, et al. Which drugs cause preventable admissions to hospital? A systematic review. Br J Clin Pharmacol 2007; 63(2): $136-147$.

4. Howard R, Avery A, Bissell P. Causes of preventable drug-related hospital admissions: a qualitative study. Qual Saf Health Care 2008; 17 (2): 109-116.

5. Pirmohamed M, James S, Meakin S, et al. Adverse drug reactions as cause of admission to hospital: prospective analysis of 18820 patients. BMJ 2004 329(7456): 15-19

6. RCGP. RCGP guide to the revalidation of general practitioners. Version 4.0 London: Royal College of General Practitioners, 2010 http://www.rcgp.org.uk/PDF/PDS Guide to Revalidation for GPs.pdf laccessed 4 Apr 2011).

7. Campbell SM, Cantrill JA, Roberts D. Prescribing indicators for UK general practice: Delphi consultation study. BMJ 2000: 321(7258): 425-428.

8. Avery AJ, Heron T, Lloyd D, et al. Investigating relationships between a range of potential indicators of general practice prescribing: an observational study. J Clin Pharm Ther 1998; 23(6): 441-450.

9. Bregnhøj L, Thirstrup S, Kristensen M, Sonne J. Reliability of a modified medication appropriateness index in primary care. Eur J Clin Pharmaco 2005; 61(10): 769-773.

10. Campbell SM, Braspenning J, Hutchinson A, Marshall M. Research methods used in developing and applying quality indicators in primary care. Qual Saf Health Care 2002; 11(4): 358-364.

11. Wenger NS, Shekelle PG, the ACOVE Investigators. Assessing care of vulnerable elders: ACOVE project overview. Ann Intern Med 2001; 135(8 pt 2) 642-646.

12. Steel N, Melzer D. Shekelle PG, et al. Developing quality indicators for older adults: transfer from the USA to the UK is feasible. Qual Saf Health Care 2004; 13(4): 260-264.

13. Fick DM, Cooper JW, Wade WE, et al. Updating the Beers criteria for potentially inappropriate medication use in older adults: results of a US consensus panel of experts. Arch Intern Med 2003; 163(22): 2716-2724.

14. Joint Formulary Committee. British National Formulary, 55th ed. London: BMJ group and RPS Publishing, 2008

15. Avery AJ. Report for NHS Connecting for Health on the production of a draft design specification for NHS IT systems aimed at minimising risk of harm to patients from medications. University of Nottingham, 2006

16. National Patient Safety Agency. http://www.npsa.nhs.uk laccessed $4 \mathrm{Apr}$ 2011).

17. National Patient Safety Agency. Medication guidance. London: National Patient Safety Agency. http://www.npsa.nhs.uk/patientsafety/medicationzone/medication-guidance/ laccessed 4 Apr 2011)

18. National Patient Safety Agency. Safety in doses: medication safety incidents in the NHS. London: National Patient Safety Agency.

http://www.npsa.nhs.uk/patientsafety/alerts-and-directives/directivesguidance/safety-in-doses/ laccessed 4 Apr 2011).

19. Department of Health. National Service Framework for older people. London: Department of Health, 2001.

20. Department of Health. Medicines for older people: implementing medicines related aspects of the NSF for older people. London: Department of Health, 2001

21. Avery AJ, Rodger S, Cantrill JA, et al. Protocol for the PINCER trial: a cluster randomised trial comparing the effectiveness of pharmacist-led IT-based intervention with simple feedback in reducing rates of clinically important errors in medicines management in general practices. Trials 2009; 10: 28

22. Morris CJ, Rodgers S, Hammersley VS, et al. Indicators for preventable drug related morbidity: application in primary care. Qual Saf Health Care 2004; 13(3): 181-185

23. Department of Health. Quality and Outcomes Framework. London: Department of Health, 2010.

http://www.dh.gov.uk/en/Healthcare/Primarycare/Primarycarecontracting/QO F/index.htm laccessed 4 Apr 2011).

24. Gallagher P, Ryan C, Byrne S, et al. STOPP (Screening Tool of Older Persons Prescriptions) and START (Screening Tool to Alert doctors to Right Treatment). Consensus validation. Int J Clin Pharmacol Ther 2008; 46(2): 72-83.

25. NHS Institute for Innovation and Improvement. The good indicators guide. Coventry: NHS Institute for Innovation and Improvement. www.apho.org.uk/resource/view.aspx?RID=44584 (accessed 11 Jul 2011).

26. Sweetman SC, (ed). Martindale: the complete drug reference. 36th edn. London: Pharmaceutical Press, 2009.

27. Baxter $\mathrm{K}$, (ed). Stockley's drug interactions a source book of interactions, their mechanisms, clinical importance and management 9th ed. London: Royal Pharmaceutical Society of Great Britain; UK Pharmaceutical Press, 2010.

28. Shekelle P. Appropriateness criteria: a useful tool for the cardiologist. Heart 2009; 95(7): 517-520.

29. RAND Health. RAND/UCLA Appropriateness Method. Santa Monica, CA RAND. http://www.rand.org/health/surveys tools/appropriateness.html (accessed 4 Apr 2011).

30. Lester HE, Campbell SM. Developing QOF indicators and the concept of Qofability. Qual Prim Care 2010; 18(2): 103-109. 


\section{Appendix 1. Detailed results from second round of RAND Appropriateness Method exercise.}

\begin{tabular}{|c|c|c|c|}
\hline Identifier & Indicator & panel median & n Consensus \\
\hline \multicolumn{4}{|c|}{ A: Cardiovascular and respiratory disease } \\
\hline $\bar{A} 1(\mathrm{a})^{\mathrm{a}}$ & Prescription of a beta-blocker to a patient with asthma & 5 & Equivocal \\
\hline$A 1(b)^{a}$ & Prescription of a non-cardioselective beta-blocker to a patient with asthma & 6 & Disagreement \\
\hline$A 1(c)^{a, b}$ & $\begin{array}{l}\text { Prescription of a beta-blocker to a patient with asthma lexcluding patients who also have a } \\
\text { cardiac condition) }\end{array}$ & 8 & Agreement \\
\hline A2 & Prescription of a nitrate to a patient with aortic stenosis & 3 & Agreement \\
\hline A3 & $\begin{array}{l}\text { Prescription of short-acting nifedipine in an older person (>65 years) (excluding patients with } \\
\text { Raynaud's disease) }\end{array}$ & 6 & Disagreement \\
\hline$A 3 X^{b, c}$ & Prescription of short-acting nifedipine (excluding patients with Raynaud's disease) & 7 & Agreement \\
\hline A4la) a & In an older person ( $>65$ years), prescription of digoxin at a dose of $>125 \mu \mathrm{g}$ daily & 7 & Equivocal \\
\hline$A 4(b)^{a, b}$ & $\begin{array}{l}\text { In a patient with renal impairment, prescription of digoxin at a dose }>125 \mu \mathrm{g} \text { daily (for example, } \\
\text { CKD } 3 \text { or worse) }\end{array}$ & 7 & Agreement \\
\hline$A 5^{b}$ & Prescription of digoxin at a dose of $>125 \mu \mathrm{g}$ daily for a patient with heart failure who is in sinus rhythm & 8 & Agreement \\
\hline$A 6^{\mathrm{b}}$ & Prescription of diltiazem or verapamil in a patient with heart failure & 8 & Agreement \\
\hline A7 $7^{b}$ & In an older patient ( $>65$ years), prescription of aspirin at a dose $>75 \mathrm{mg}$ daily & 7 & Agreement \\
\hline$A 7 X^{b, c}$ & In an older patient ( $>65$ years), prescription of aspirin at a dose $>75 \mathrm{mg}$ daily for $\geq 1$ month & 8 & Agreement \\
\hline A8 & In a patient with heart failure, the prescription of a high-sodium content drug & 3 & Equivocal \\
\hline A9la) a & In an older patient ( $>65$ years) with an arrhythmia, the prescription of a tricyclic antidepressant & 4 & Equivocal \\
\hline$A 9(b)^{a}$ & $\begin{array}{l}\text { In an older patient ( }>65 \text { years) with a cardiac conductive abnormality, the prescription of a tricyclic } \\
\text { antidepressant }\end{array}$ & 4 & Equivocal \\
\hline A10 & In a patient with a history of gout, the prescription of a thiazide diuretic & 3 & Agreement \\
\hline $\mathrm{A} 11^{\mathrm{b}}$ & $\begin{array}{l}\text { The prescription of a long-acting beta- } 2 \text { agonist inhaler to a patient with asthma who is not also } \\
\text { using an inhaled corticosteroid }\end{array}$ & 8 & Agreement \\
\hline \multicolumn{4}{|c|}{ B: Central nervous system (including analgesics) } \\
\hline B1(a) $)^{a, b}$ & Prescription of aspirin to a child aged $\leq 16$ years & 9 & Agreement \\
\hline$B 1(b)^{a, b}$ & Prescription of aspirin to a child aged $\leq 16$ years, where the child does not have Kawasaki's disease & 9 & Agreement \\
\hline B2 & In a patient with epilepsy, the prescription of a drug that may lower the seizure threshold & 3 & Agreement \\
\hline B3(a) $)^{\mathrm{a}, \mathrm{b}}$ & In a patient with Parkinson's disease, the prescription of metoclopramide & 8 & Agreement \\
\hline $\mathrm{B} 3(\mathrm{~b})^{\mathrm{a}, \mathrm{b}}$ & In a patient with Parkinson's disease, the prescription of prochlorperazine & 8 & Agreement \\
\hline$B 4(a)^{a}$ & In an older person (>65 years) the prescription of a benzodiazepine on a long-term basis (that is, $>1$ month) & 4.5 & Equivocal \\
\hline$B 4(a) X^{a, c}$ & $\begin{array}{l}\text { In an older person (>65 years) the prescription of a benzodiazepine or Z-drug on a long-term basis } \\
\text { (that is, }>1 \text { month) }\end{array}$ & 4.5 & Disagreement \\
\hline$B 4(b)^{a, b}$ & $\begin{array}{l}\text { In an older person ( }>65 \text { years) who is not receiving benzodiazepines on a long-term basis, the } \\
\text { prescription of a benzodiazepine for }>21 \text { days }\end{array}$ & 8 & Agreement \\
\hline$B 4(b) X^{a, b, c}$ & $\begin{array}{l}\text { In an older person ( }>65 \text { years) who is not receiving benzodiazepines or Z-drugs on a long-term basis, } \\
\text { the prescription of a benzodiazepine or Z-drug for }>21 \text { days }\end{array}$ & 8 & Agreement \\
\hline B5(a) & $\begin{array}{l}\text { In an older person (>65 years) with depression, the prescription of a long-term benzodiazepine } \\
\text { (that is, }>21 \text { days) }\end{array}$ & 5 & Disagreement \\
\hline B5(a) Xc & $\begin{array}{l}\text { In an older person ( }>65 \text { years) with depression, the prescription of a long-term benzodiazepine or Z-drug } \\
\text { (that is, }>21 \text { days) }\end{array}$ & 6 & Disagreement \\
\hline$B 5(b)^{a}$ & $\begin{array}{l}\text { In an older person ( }>65 \text { years) with depression initiation of benzodiazepine on a long-term basis } \\
\text { (that is, }>21 \text { days) }\end{array}$ & 8 & Equivocal \\
\hline$B 5(b) X^{a, b, c}$ & $\begin{array}{l}\text { In an older person (>65 years) with depression initiation of benzodiazepine or Z-drugs on a long-term } \\
\text { basis (that is, }>21 \text { days) }\end{array}$ & 8 & Agreement \\
\hline B6 & In a patient with COPD, the prescription of a benzodiazepine & 4 & Agreement \\
\hline$B 6 X^{c}$ & In a patient with COPD, the prescription of a benzodiazepine or Z-drug & 4 & Agreement \\
\hline B7(a) & $\begin{array}{l}\text { In an older patient (>65 years) with a history of falls, the prescription of either a benzodiazepine, an } \\
\text { antipsychotic, or a tricyclic antidepressant }\end{array}$ & 3 & Agreement \\
\hline$B 7(a) X^{a, c}$ & $\begin{array}{l}\text { In an older patient (>65 years) with a history of falls, the prescription of a benzodiazepine, a Z-drug, an } \\
\text { antipsychotic, or a tricyclic antidepressant }\end{array}$ & 3 & Agreement \\
\hline$B 7(b)^{a}$ & In an older patient ( $>65$ years) with a history of falls, the prescription of a benzodiazepine & 4 & Equivocal \\
\hline$B 7(b) X a, c$ & In an older patient (>65 years) with a history of falls, the prescription of a benzodiazepine or Z-drug & 4 & Equivocal \\
\hline $\mathrm{B} 7(\mathrm{c})^{\mathrm{a}}$ & In an older patient ( $>65$ years) with a history of falls, the prescription of an antipsychotic & 3.5 & Equivocal \\
\hline$B 7(d)$ a & In an older patient ( $>65$ years) with a history of falls, the prescription of a tricyclic antidepressant & 3.5 & Equivocal \\
\hline B8 & $\begin{array}{l}\text { In an older patient ( }>65 \text { years) with hyponatraemia/syndrome of inappropriate antidiuretic hormone } \\
\text { secretion, the prescription of a selective serotonin reuptake inhibitor }\end{array}$ & 4 & Equivocal \\
\hline B9 & In an older person ( $>65$ years) with cognitive impairment, the prescription of an anti-muscarinic drug & 3.5 & Equivocal \\
\hline B10 & In a patient with angle closure glaucoma, the prescription of an anti-muscarinic drug & 4 & Equivocal \\
\hline \multicolumn{4}{|c|}{ C: Anti-infective agents } \\
\hline C1 & Prescription of a tetracycline to a child aged $>12$ years & 5 & Equivocal \\
\hline C2(a) & Prescription of mefloquine to a patient with a history of psychiatric disorder (including depression) & 6 & Disagreement \\
\hline$C 2(b)^{a, b}$ & Prescription of mefloquine to a patient with a history of convulsions & 8 & Agreement \\
\hline$C 2(b) X^{a, c}$ & Prescription of mefloquine to a patient with a history of epilepsy & 3 & Equivocal \\
\hline C3 & In an older patient ( $>65$ years) long-term prescription of nitrofurantoin (that is, $\geq 28$-day prescription) & 6 & Disagreement \\
\hline
\end{tabular}




\begin{tabular}{|c|c|c|c|}
\hline Identifier & Indicator & panel median & Consensus \\
\hline \multicolumn{4}{|c|}{ D: Women's health and urinary disorders } \\
\hline $\bar{D} 1^{b}$ & $\begin{array}{l}\text { Prescription of a combined hormonal contraceptive to a woman with a history of venous or } \\
\text { arterial thromboembolism }\end{array}$ & 9 & Agreement \\
\hline $\mathrm{D} 2(\mathrm{a})^{\mathrm{a}, \mathrm{b}}$ & Prescription of oral or transdermal oestrogens to a woman with a history of breast cancer & 9 & Agreement \\
\hline $\mathrm{D} 2(\mathrm{~b})^{\mathrm{a}}$ & Prescription of a topical (vaginal) oestrogen to a woman with a history of breast cancer & 5 & Equivocal \\
\hline D3 $^{\mathrm{b}}$ & Prescription of oral or transdermal oestrogen without progesterone in a woman with an intact uterus & 9 & Agreement \\
\hline D4 & Prescription of an anti-muscarinic drug to a patient with bladder outflow obstruction & 3 & Agreement \\
\hline D5Xa,b,c & Prescription of a combined hormonal contraceptive to a woman aged $\geq 35$ years who is a current smoker & 8.5 & Agreement \\
\hline $\mathrm{D} 6 \mathrm{X}^{\mathrm{b}, \mathrm{c}}$ & Prescription of a combined hormonal contraceptive to a woman with body mass index of $\geq 40$ & 8 & Agreement \\
\hline \multicolumn{4}{|c|}{ E: Musculoskeletal } \\
\hline E1(a) $)^{a, b}$ & Prescription of a non-selective NSAID to a patient with a history of peptic ulceration & 8 & Agreement \\
\hline$E 1(a) X^{a, b, c}$ & Prescription of an NSAID to a patient with a history of peptic ulceration & 9 & Agreement \\
\hline E1(b) & Prescription of a non-selective NSAID to an older patient ( $>65$ years) with a history of peptic ulceration & 8 & Agreement \\
\hline $\mathrm{E} 1(\mathrm{~b}) \mathrm{X}^{\mathrm{a}, \mathrm{b}, \mathrm{c}}$ & Prescription of an NSAID to an older patient ( $>65$ years) with a history of peptic ulceration & 9 & Agreement \\
\hline $\mathrm{E} 1(\mathrm{c})^{\mathrm{a}, \mathrm{b}}$ & $\begin{array}{l}\text { Prescription of a non-selective NSAID, without co-prescription of an ulcer healing drug, to a patient } \\
\text { with a history of peptic ulceration }\end{array}$ & 8 & Agreement \\
\hline$E 1(c) X^{a, b, c}$ & $\begin{array}{l}\text { Prescription of an NSAID, without co-prescription of an ulcer healing drug, to a patient with a history } \\
\text { of peptic ulceration }\end{array}$ & 9 & Agreement \\
\hline E2 & $\begin{array}{l}\text { Prescription of a selective COX-2 inhibitor NSAID to a patient with cardiovascular disease } \\
\text { (for example, CHD, cerebrovascular disease, or peripheral arterial disease) }\end{array}$ & 3 & Equivocal \\
\hline E3 & $\begin{array}{l}\text { In an older patient (>65 years), prescription of an NSAID without co-prescription of an ulcer } \\
\text { healing drug (for example, misoprostol or a proton pump inhibitor) }\end{array}$ & 6 & Equivocal \\
\hline E4 & $\begin{array}{l}\text { In an older patient ( }>65 \text { years), prescription of a long-term ( } \geq 28 \text { days) full-dosage, longer half-life } \\
\text { non-COX-2-selective NSAID }\end{array}$ & 4 & Equivocal \\
\hline $\mathrm{E}^{\mathrm{b}}$ & In an older patient ( $>65$ years) with heart failure, the prescription of an NSAID & 8 & Agreement \\
\hline$E 5 X^{b, c}$ & In a patient with heart failure, the prescription of an NSAID & 8 & Agreement \\
\hline E6 $6^{\mathrm{b}}$ & $\begin{array}{l}\text { In an older patient ( }>65 \text { years) with chronic renal failure, the prescription of an NSAID } \\
\text { (for example, CKD } 3 \text { or worse) }\end{array}$ & 8 & Agreement \\
\hline $\mathrm{E} 6 \mathrm{X}^{\mathrm{b}, \mathrm{c}}$ & In a patient with chronic renal failure, the prescription of an NSAID (for example, CKD 3 or worse) & 8.5 & Agreement \\
\hline E7 & $\begin{array}{l}\text { In an older patient ( }>65 \text { years) prescription of a long-term ( }>28 \text { days) NSAID lexcept for } \\
\text { ibuprofen } \leq 1200 \mathrm{mg} \text { daily) }\end{array}$ & 7 & Agreement \\
\hline \multicolumn{4}{|c|}{ F: Hazardous co-prescriptions, interactions, and allergy } \\
\hline F1 & Prescription of warfarin and aspirin in combination, without co-prescription of an ulcer healing drug & 6 & Disagreement \\
\hline $\mathrm{F}^{\mathrm{b}}$ & Prescription of warfarin in combination with an oral NSAID & 7.5 & Agreement \\
\hline $\mathrm{F}^{\mathrm{b}}$ & $\begin{array}{l}\text { Prescription of a phosphodiesterase type- } 5 \text { inhibitor (for example, sildenafil) to a patient } \\
\text { who is also receiving a nitrate or nicorandil }\end{array}$ & 8 & Agreement \\
\hline F4(a) a & Prescription of clarithromycin or erythromycin to a patient who is also receiving simvastatin & 4.5 & Disagreement \\
\hline $\mathrm{F} 4(\mathrm{~b})^{\mathrm{a}, \mathrm{b}}$ & $\begin{array}{l}\text { Prescription of clarithromycin or erythromycin to a patient who is also receiving simvastatin, with } \\
\text { no evidence that the patient has been advised to stop the simvastatin while taking the antibiotic }\end{array}$ & 7 & Agreement \\
\hline $\mathrm{F} 5(\mathrm{~b})^{\mathrm{a}, \mathrm{b}}$ & $\begin{array}{l}\text { Prescription of a potassium salt or potassium-sparing diuretic lexcluding aldosterone antagonists, such } \\
\text { as spironolactone) to a patient who is also receiving an ACE inhibitor or angiotensin II receptor antagonist }\end{array}$ & 8 & Agreement \\
\hline $\mathrm{F}^{\mathrm{b}}$ & Prescription of verapamil to a patient who is also receiving a beta-blocker drug & 8 & Agreement \\
\hline F7 & Prescription of quinine to a patient who is also receiving a cardiac glycoside, for example, digoxin & 5 & Equivocal \\
\hline F8 & Prescription of ciprofloxacin or norfloxacin to a patient who is also receiving theophylline & 5 & Agreement \\
\hline Fqb & Prescription of a penicillin-containing preparation to a patient with a history of allergy to penicillin & 8.5 & Agreement \\
\hline F10 & Prescription of warfarin and aspirin in combination & 6 & Equivocal \\
\hline
\end{tabular}


